\title{
A CLINICAL STUDY ON LAPAROTOMY FINDINGS IN BLUNT INJURY ABDOMEN
}

\author{
Mudavatu Bhagavan Naik¹, Gali Satya Navamani², E. V. Durganeelima ${ }^{3}$
}

1 Professor, Department of Surgery, Guntur Medical College and Government General Hospital, Guntur, Andhra Pradesh. ${ }^{2}$ Assistant Professor, Department of Surgery, Guntur Medical College and Government General Hospital, Guntur, Andhra Pradesh. 3Junior Resident, Department of Surgery, Guntur Medical College and Government General Hospital, Guntur, Andhra Pradesh.

\section{BACKGROUND} ABSTRACT

Blunt injury abdomen is most commonly caused by road traffic accidents. The rapid increase in number of motor vehicles and its aftermath has caused rapid increase in number of victims of blunt abdominal trauma. Motor vehicle accidents account for $75 \%$ $80 \%$ of blunt abdominal trauma.

\section{MATERIALS AND METHODS}

The present study comprises of 50 patients with blunt abdominal injuries admitted in surgical wards from December 2015 to November 2017. Patients were methodically enquired according to the proforma approved by the guide. A detailed history as to the mode of injury, thorough clinical examination and necessary investigations like routine investigations, special investigations including ultrasound and CT scan were done.

\section{RESULTS}

In this study, majority belonged to 21 - 30 years of age accounting to 42 percent followed by $31-40$ years of age (22\%). Sex wise distribution showed that majority (92\%) were males and only $8 \%$ were females. Ultrasonography of abdomen was done in all 50 cases. Injury to spleen was most common (38\%) followed by liver in $24 \%$ of cases on Ultrasonography abdomen. CECT was done in 35 cases. In CECT also, spleen was the most common organ to be injured (34.3\%) followed by liver (28.6\%) and hollow viscus (25.7\%). A total of three patients died in this study.

\section{CONCLUSION}

Blunt injury abdomen with solid organ injury forms considerable load of patients in our society. Measures for early transport of the patients from the accident site to the trauma centres should be undertaken. Early diagnosis and repeated clinical examination and use of appropriate investigation form is the key to managing blunt injury abdomen patients.

\section{KEYWORDS}

Blunt Injury Abdomen, Laparotomy, Surgery, Road Traffic Accidents.

HOW TO CITE THIS ARTICLE: Naik MB, Navamani GS, Durganeelima EV. A clinical study on laparotomy findings in blunt injury abdomen. J. Evolution Med. Dent. Sci. 2018;7(18):2188-2191, DOI: 10.14260/jemds/2018/492

\section{BACKGROUND}

Blunt injury abdomen is most commonly caused by road traffic accidents. The rapid increase in number of motor vehicles and its aftermath has caused rapid increase in number of victims of blunt abdominal trauma. Motor vehicle accidents account for $75 \%-80 \%$ of blunt abdominal trauma. Blunt abdominal injury is also a result of fall from height, assault with objects, industrial mishaps, sports injuries, bomb blast and fall from riding bicycle. ${ }^{[1,2]}$

Blunt abdominal trauma is usually not obvious, hence often missed unless repeatedly looked for. Due to the delay in diagnosis and inadequate treatment of the abdominal injuries, most of the cases are fatal. The knowledge in the management of blunt abdomen is progressively increasing. In spite of the best techniques and advances in diagnostic and supportive care, the mortality and morbidity remains at large. The reason for this could be due to the

'Financial or Other Competing Interest': None.

Submission 06-04-2018, Peer Review 18-04-2018,

Acceptance 20-04-2018, Published 30-04-2018.

Corresponding Author:

Dr. Gali Satya Navamani,

Flat No. 509, B-Block,

Rishi Valley Homes, Opp. ITC near IMA Hall,

Guntur-522004, Andhra Pradesh.

E-mail:dr.satyanavamani@gmail.com

DOI: $10.14260 /$ jemds $/ 2018 / 492$ interval between trauma and hospitalisation, inadequate and lack of appropriate surgical treatment, delay in diagnosis, post-operative complications and associated trauma especially to head and thorax.[3,4] In view of increasing number of vehicles and consequently road traffic accidents, this dissertation has been chosen to study the cases of blunt injury abdomen presenting at Govt. General Hospital, Guntur attached to Guntur Medical College.

\section{MATERIALS AND METHODS}

\section{Source of Data and Period of Study}

The present study "A CLINICAL STUDY ON LAPAROTOMY FINDINGS IN BLUNT INJURY ABDOMEN" comprises of patients admitted to and operated in various surgical units in the Department of Surgery at Government General Hospital, Guntur, attached to Guntur Medical College, Guntur, from December 2015 to November 2017. Study design was a case series.

\section{Collection of Data, Sample Size and Mode of Selection}

50 patients with blunt abdominal injuries admitted to surgical wards were included in the study. Patients were methodically enquired according to the proforma approved by the guide. A detailed history as to the mode of injury, thorough clinical examination and necessary investigations like routine investigations, special investigations including ultrasound and CT scan were done. 


\section{Inclusion Criteria}

All patients with blunt abdominal injury for whom laparotomy was done with intra-abdominal injuries were included in the study.

\section{Exclusion Criteria}

Patients who died before confirmation of definitive diagnosis were excluded from this study.

\section{Method}

The management was individualised, and each case was assessed on its own. In patients where laparotomy was performed after resuscitation, the details regarding the viscera injured and nature of surgery performed were recorded.

Each case was carefully followed up to evaluate the progress of patient and to note the development of complications if any and its management.

\section{Statistical Analysis}

The details of all cases are summarised in the master chart and results of the study have been analysed in detail. Statistical analysis was done using Microsoft Excel 2010 version. Data was presented in percentages and proportions.

\section{RESULTS}

From December 2015 to November 2017, 50 number of cases were studied which belonged to surgical units in Government General Hospital, Guntur.

In this study, majority belonged to 21 - 30 years of age accounting to 42 percent followed by 31 - 40 years of age (22\%). Sex wise distribution showed that majority (92\%) were males and only $8 \%$ were females.

With regards to mode of injury, in $86 \%$ of cases mode of injury is road traffic accidents followed by fall from height accounting to $8 \%$. Least was agricultural work-based injury.

\section{Clinical Presentation}

$84 \%$ of the patients presented with abdominal pain followed by abdominal guarding and rigidity. Only $8 \%$ of patients presented with shock.

Latent period which is the time interval between time of injury to time of presentation to the hospital. $64 \%$ of people presented within first 12 hrs. of injury. 28\% between 12 - 24 hours and $8 \%$ people late period of upto 4 days.

Associated injury along with abdominal injury was present in 37 cases. The common extra-abdominal injury was thoracic in the form of fractured ribs and haemothorax followed by extremities fracture, head injury, pelvis and soft tissue injury.

\section{Investigations}

Haemoglobin was above $10 \mathrm{gm}$ in $38 \%$ of patients and was below $8 \mathrm{gm}$ in $26 \%$ of cases. Haematocrit was done in 45 patients. It was below 30 in $40 \%$ of the patients.

Urine microscopy showed RBCs in $20 \%$ of cases and normal in $80 \%$ of cases.

Plain X-ray Erect Abdomen was done in 46 cases and was not done in 4 cases, as they were haemodynamically unstable. $20 \%$ of x-ray Erect Abdomen was normal in our study.

Four Quadrant Aspiration (FQA) was positive in 30 cases, negative in 14 cases and not done in 6 cases.
Ultrasonography of abdomen was done in all 50 cases. Injury to spleen was most common (38\%) followed by liver in $24 \%$ of cases on Ultrasonography abdomen.

\begin{tabular}{|c|c|c|}
\hline Organ & No. of Cases & Percentage \\
\hline Spleen & 19 & 38 \\
\hline Liver & 12 & 24 \\
\hline Kidney & 1 & 2 \\
\hline Pancreas & 2 & 4 \\
\hline Hollow Viscus & 0 & 0 \\
\hline Mesentery & 0 & 0 \\
\hline \multicolumn{2}{|c|}{ Table 1. Organ Injury in USG Abdomen } \\
\hline
\end{tabular}

\begin{tabular}{|c|c|c|}
\hline Organ Injured & No. of Cases & Percentage \\
\hline Spleen & 12 & $34.3 \%$ \\
\hline Liver & 10 & $28.6 \%$ \\
\hline Hollow Viscus & 9 & $25.7 \%$ \\
\hline Pancreas & 3 & $8.6 \%$ \\
\hline Kidney & 1 & $2.8 \%$ \\
\hline \multicolumn{2}{|c|}{ Table 2. CECT Abdomen } \\
\hline
\end{tabular}

CECT was done in 35 cases. In CECT also, spleen was the most common organ to be injured (34.3\%) followed by liver (28.6\%) and hollow viscus $(25.7 \%)$. Those patients who did not undergo CECT, either they were taken for laparotomy or haemodynamically unstable.

\section{Types of Surgery}

The below data shows various operative procedures carried out during exploratory laparotomy.

\begin{tabular}{|c|c|c|}
\hline Procedure & $\begin{array}{c}\text { No. of } \\
\text { Patients }\end{array}$ & Percentage \\
\hline Splenectomy & 11 & 22 \\
\hline Hepatorrhaphy & 8 & 16 \\
\hline Closure of perforation & 7 & 14 \\
\hline Splenorrhaphy & 4 & 8 \\
\hline Resection anastomosis & 4 & 8 \\
\hline Drainage procedure & 3 & 6 \\
\hline $\begin{array}{l}\text { Splenorrhaphy and mesenteric } \\
\text { closure }\end{array}$ & 3 & 6 \\
\hline Mesenteric rent closure & 2 & 4 \\
\hline Colostomy & 2 & 4 \\
\hline $\begin{array}{l}\text { Hepatorrhaphy and Mesenteric } \\
\text { closure }\end{array}$ & 1 & 2 \\
\hline $\begin{array}{l}\text { Resection anastomosis and } \\
\text { mesenteric closure }\end{array}$ & 1 & 2 \\
\hline Hepatorrhaphy and Splenorrhaphy & 1 & 2 \\
\hline $\begin{array}{l}\text { Resection anastomosis and } \\
\text { pancreatic tube }\end{array}$ & 1 & 2 \\
\hline $\begin{array}{l}\text { Hepatorrhaphy and closure of } \\
\text { perforation and resection } \\
\text { anastomosis }\end{array}$ & 1 & 2 \\
\hline \multicolumn{3}{|c|}{ Table 3. Type of Surgery } \\
\hline
\end{tabular}

Among the total cases 3 developed wound infections, 5 had respiratory complications, one case each developed wound dehiscence and intra-abdominal abscess respectively post operatively. Mean duration of stay in the hospital was 16 days and ranged from 10 - 54 days.

\section{Mortality}

Total three patients died in this study. Two cases have pancreatic injury. One case had duodenal transection injury 
along with grade IV pancreatic injury. Therefore, the mortality rate was 6 percent.

\section{DISCUSSION}

Males are more common victims of blunt trauma abdomen and the incidence is slightly more in males, as males are more involved in RTA.

Similar findings were seen in Davis et al study (70\% males) and Vignesh et al study[5] (75\%) males.

\section{Age Group}

In our study, majority of the population belonged to $21-30$ yrs. of age followed by $31-40$ yrs. of age, as young people are involved in RTA which is comparable to Davis et al and Vignesh et al.[5]

\section{Mode of Injury}

RTA is the most common mode of injury, because of increased number of vehicles recently. The young people also give priority to speed rather than safety. These findings were in concurrence with findings from Davis et al $(70 \%)$ and Vignesh et al[5] (57\%), which were due to road traffic accidents.

\section{Clinical Presentation}

In our study, abdominal pain was the most common presenting complaint accounting to $84 \%$. Peritonitis was the next most common presentation in $56 \%$ of patients. The signs and symptoms are misleading in case of blunt trauma abdomen and are masked by concomitant head injury, chest injury and alcohol consumption. Retroperitoneal organ injury was missed in USG abdomen.

In Davis et al study, $43 \%$ had no specific complaints. So, this emphasises the importance of careful and continuing observation and repeated clinical examination of individual with-

\section{Latent Period}

Latent period is the interval between the time of injury to presentation to our hospital. In our study, $64 \%$ of patients presented between 1 - $12 \mathrm{hrs}$. after injury. 24\% presented 12 $-24 \mathrm{hrs}$. after surgery. This time lag is due to lack of facility for transport, patient's tolerance of pain in rural areas, negligence of attenders and lack of proper health care at peripheral centres.

\section{Ultrasound Examination}

USG abdomen (Focussed assessment with sonography for trauma) was done in all cases, out of which 42 cases have solid organ injury. Free fluid in abdomen was found in nearly 45 cases. Therefore, USG was more reliable in solid organ injury than hollow viscus injury.

\begin{tabular}{|c|c|c|c|c|c|}
\hline Organ & $\begin{array}{c}\text { \% in our } \\
\text { Study }\end{array}$ & $\begin{array}{c}\text { Cusheri } \\
\text { et al[6] }\end{array}$ & $\begin{array}{c}\text { Davis } \\
\text { et al }\end{array}$ & $\begin{array}{c}\text { Cox } \\
\text { et al[7] }\end{array}$ & $\begin{array}{c}\text { Khanna } \\
\text { et al[8] }\end{array}$ \\
\hline Spleen & $38 \%$ & $25 \%$ & $25 \%$ & $46 \%$ & $26 \%$ \\
\hline Liver & $24 \%$ & $15 \%$ & $16 \%$ & $33 \%$ & $37 \%$ \\
\hline \multicolumn{6}{|c|}{ Table 4. Comparison of Results of USG (FAST) } \\
\hline
\end{tabular}

From the above table splenic injury is the most common finding in USG followed by liver injury. Relatively less specific in hollow viscus injury.
Imaging is essential in early decision making. Focussed assessment with sonography in trauma (FAST) examination of pericardial, perihepatic, perisplenic and pelvis areas help in early detection of clinically significant abdominal injury. FAST examination can be performed repeatedly and is an excellent adjuvant to physical examination.

CECT abdomen: CECT was done in 35 cases. Six patients who presented in shock were immediately taken for laparotomy after FAST. It can accurately diagnose the grade of solid organ injury. It can also pick up retroperitoneal organ injury like kidney and pancreas.

In our study CECT was accurate for 12 cases of spleen, 10 cases of liver, detected 3 out of 5 cases of pancreatic injury. It also helped to detect hollow viscus injury non-specifically upto $18 \%$ of the cases.

\begin{tabular}{|c|c|c|c|c|}
\hline Organ & $\begin{array}{c}\text { Our } \\
\text { Study }\end{array}$ & $\begin{array}{c}\text { Davis } \\
\text { et al }\end{array}$ & $\begin{array}{c}\text { Cox } \\
\text { et al[7] }\end{array}$ & $\begin{array}{c}\text { Allen } \\
\text { et al[9] }\end{array}$ \\
\hline Spleen & $36 \%$ & $25 \%$ & $46 \%$ & \\
\hline Liver & $24 \%$ & $16 \%$ & $33 \%$ & $33 \%$ \\
\hline Kidney & $2 \%$ & & & \\
\hline $\begin{array}{c}\text { Bowel } \\
\text { Injury }\end{array}$ & $34 \%$ & & & \\
\hline Pancreas & $20 \%$ & & & \\
\hline Table 5. Organ Injury Comparison with Other Studies \\
\hline
\end{tabular}

Our study has similar percentage in case of splenic injury followed by liver injury and bowel injury. Bowel injury has same percent when compared with Hackman et al study. Splenic injury has relatively similar incidence when compared with Davis et al and Cox et al[7] studies.

Our study has similar rate of Splenectomy (22 cases) when compared to other studies of Yogesh et al (53\%) followed by primary closure with Hepatorrhaphy. In our study, most common GIT surgery performed is resection and anastomosis similar to other studies.

\section{CONCLUSION}

Blunt injury abdomen with solid organ injury forms considerable load of patients in our society. Most common age group involved is 21 - 30 years. Predominantly, males are affected in large proportions. Road traffic accidents forms the most common mode of injury. So, efforts should be made to bring road traffic regulations into strict action and traffic norms regulated. The well-established trauma care centres should be established at every Taluk hospitals.

Measures for early transport of the patients from the accident site to the trauma centres should be undertaken. Significant number of cases will have associated injuries with blunt injury abdomen like head injury, thoracic injury and extremity fractures. Blunt injury abdomen is usually less obvious. Hence, repeated examinations by multispecialty personnel in a specialised trauma centre is required. Erect abdomen x-ray is a useful investigation to identify associated hollow viscus injury. Falling titres in serial haematocrit value indicates ongoing bleeding.

With advent of high resolution, ultrasonography (FAST) and FQA, investigations are becoming less opted. CECT forms the core investigation of choice in dealing with blunt injury abdomen patients and becomes more important in deciding operative versus conservative management. Early diagnosis and repeated clinical examination and use of appropriate investigation form the key in managing blunt injury abdomen 
patients. Associated extra-abdominal injuries like head, thoracic and orthopaedic injuries influenced the morbidity and mortality of the patients.

\section{REFERENCES}

[1] Townsend CM. Sabiston textbook of surgery. Vol. 19. 19th edn. Philadelphia, PA: Saunders 2012: p. 455-9.

[2] Meyer AA, Crass RA. Abdominal trauma. Surg Clin North Am 1982;62:105-11.

[3] Davis JJ, Cohn I Jr, Nance FC. Diagnosis and management of blunt abdominal trauma. Ann Surg 1976;183(6):672-8.

[4] Patel P, Gadhavi J, Parmar H. A study of blunt and penetrating abdominal trauma, its various patterns of injuries and its management. Int J Med Sci Public Health 2016;5(7):1309-12.
[5] Vignesh T, ArunKumar AS, Kamat V. Outcome in patients with blunt chest trauma and pulmonary contusions. Indian J Crit Care Med 2004;8(2):73-7.

[6] Cusheri A, Hanna GAR. Essential surgical practice. $4^{\text {th }}$ edn. Butterworth International 2013: p. 263-304.

[7] Cox EF. Blunt abdominal trauma: a 5 year analysis of 870 patients requiring celiotomy. Ann Surg 1984;199(4):467-74.

[8] Khanna R, Khanna S, Singh P, et al. Spectrum of blunt abdominal trauma in Varanasi. Quart J 1999;35(1\&2):25-8.

[9] Allen RB, Curry GJ. Abdominal trauma: a study of 297 consecutive cases. Am J Surg 1957;93(3):398-404. 